\title{
ECOLOGICAL STUDIES ON PREDACEOUS AND PARASITIC MITES ASSOCIATED WITH SOME STORED PRODUCTS
}

\author{
Wedad A. Atwa(1), M. E. El-Naggar(2), A. M. Khalil(2), Manal E. El-Shaer(1) \\ and Zeinab M.M. Mostafa ${ }^{(2)}$ \\ (1) Department of Zoology Faculty of Science Al-Azhar University \\ (2) Plant Protection Research Institute, A.R.C., Dokki, Egypt
}

Received: Aug. 15, 2018

Accepted: Sep. 22, 2018

ABSTRACT: The occurrence of mites associated with stored products was estimated at different regions of Giza governorate, Egypt ( $6^{\text {th }}$ October City, Osim, Al-aiat, Faisal, Dahshour and El-Baragil). The seven localities were chosen to conduct this study along three years (2016-2018). Seventy-nine mite species belonging to 44 genera, 22 families and 4 suborders were collected from examined stored products e.g. (chocolate, dried molokhia, wheat flour, maize, bean, rice, date palm fruits, hulling rice, wheat grain, dried fig, turkey cheese, wheat flour, dried milk, peanut). The obtained results indicated that Acarus farrie, Dermatophagoides pteronyssinus, and Blomia freemani were the dominant astimatidmites in all examined store products. Whereas, Cheletogenes ornatus, Blattisecius keegani and Hypoaspis oseii were the most common predatory mites. The highest population of astimatid mites was recorded in March and the lowest level was recorded during August on wheat grain. While . on dried fig the astigmatid mites reached the highest population during April, whereas, the lowest population was recorded during August, along the two successive years.

Key words: Stored product, mites, grains, population, occurrence, Astigmata.

\section{INTRODUCTION}

Mites inhabited mainly the stored food and plant materials. In stored plant grain and oilseeds mite infestations were studied intensively allover the world. Among the next commodities well documented are the mite infestation in cereal based food, dried fruits, root crops and ornamental plants, as well as chesses (Hughes, 1976). The study of mite populations in stores is important, due to that mites cause severe damage in these products (Solomon, 1946). Knowledge of the distribution of pests in storerooms is important from the point of view of their ecology as well as their control (Zdarkova et al., 1983). Storage mites are mainly found in stored products such as dried eggs, ham, herring meal, cheese, and different kinds of nuts (Olsson and Hamsten, 2000). The mite infestation decrease food safety because mites are allergen products and transmit mycotoxin- producing fungi (Hubert et al., 2003).

Damage by insects, mites fungi, and sprouting causes hundreds millions of dollars of economic losses to grain producers, merchandisers, and processors each year (Harein and Meronuck 1995). The mites cause direct and indirect damage to stored grains and their products by raising their moisture content, generation sufficient heat for the growth of infection bacteria and fungi. The acarid mite, Tyrophagus putrescentia (Schrank) can infest a wide range of food stuffs, plant and animal materiasl where environmental conditions are suitable, and is considered to be a cosmopolitan stored product pest of significant economic and sanitary importance. Tyrophagus putrescentia is most frequently found in stored food with a relatively high fat and protein content, such as wheat and Soy, flour, cheese, rye 
bread, herring meal, bacon, dried milk and various seeds (Duek et al., 2001). Many studies on the incidence of storage mites have been reported by El Nggar et al., (1992), Fawzy (1996), Mohamed (2003), El- Sanady, (2005), Mostafa et al., (2006), Yassin et al., (2009), Abou-El Enien, (2011), Abdel-Khalik (2013) and ElSayed (2017) in Egypt who recorded different mite species in different varieties of stored products.

This study was conducted to throw a light on the incidence, distribution and dynamics of mite populations in different stored products.

\section{MATERIALS AND METHODS}

In this study, different regions of Giza governorate $\left(6^{\text {th }}\right.$ October City, Osim, AlAiat, Faisal, Dahshour and El-Baragil) were chosen to achievement this study.

Collection of mites and identification:

Samples of different stored products (wheat, biscuit, onion, cheese, dried milk, wheat grains, rice grain, bran, garlic bulbs, chocolate, cowpea, maize grains, soy bean, date palm fruits, barley, hulling rice, dry molokhia, cow pea, dried fig, peanut, lentil, and broken bean grains), were collected monthly during two consecutive years (2016/ 2018). The mites samples were brought to Acarology Research Laboratory in cotton and field crops Acarology Department, Plant protection Research Institute, Agricultural Research Center, for examination in the same collection day. Plastic bags were used to transfer samples to Laboratory, and were marked by a label denoting data. For extracting mites, samples of $\mathbf{2 5 0} \mathbf{g m}$ were used and separated using the modified Tullgren funnels. Mites were received in Petridishes $(6 \mathrm{~cm}$. Diameter, high $1.5 \mathrm{~cm})$. Half -filled with water and smearing its sides with a layer of Vaseline to prevent mites escaping. Extracted mites were cleared in Nesbitt's solution, then mounted in
Hoyer's medium on glass slides. Specimens were identified and classified into their taxonomical rank by using different specific keys (Griffiths, 1960; Hughes, 1976; Lindquist and Evans, 1965; Summer and Price, 1970; Karg, 1971; Johnston, 1975; Zaher, 1984 and 1986; and Krantz and Walter, 2009).

\section{Population dynamics study:}

During the study season from (2016 to 2018) the wheat grains and Dried fig fruits had chosen to estimate the infestation of the different mites to these hosts at Dahshour region, Giza governorate, it was found that the commonest collected mites were belonging to suborder Acaridida, Actinedida and Gamasida. The population dynamics of these mites in relation to abiotic factors and biotic factors was calculated.

\section{Statistical analysis:}

Data were analyzed by correlation coefficient between the mite population and weather factors using SAS statistical software (SAS Institute, 2010).

\section{RESULTS AND DISCUSSION}

A. Ecological study:

\section{A.1. Survey study:}

A large number of mites are known to infest different varieties of stored products throughout the world. The current study was carried out during the period of 2016- 2018 in different locations to record the mites associated with different stored products at El-Giza governorate. These regions were 6th October city, Osim, Faisal, Dahshour, ElBaragil and Al-Aiat. This work as shown in Table (1) proves the occurrence of (79) mite species belonging to (45) genera under (22) families. These families are belonging to 4 suborders: Acaridida (Astigmata), Actinedida (Prostigmata) and Gamasida (Mesostigmata) and Oribatidae (Cryptostigmata) collected 
from different stored products e.g. (chocolate, dried molokhia, wheat flour, maize, bean, rice, date palm fruits, hulling rice, wheat grain, dried fig, turkey cheese, wheat flour, dried milk, peanut. etc). Table (1) also shows the collected mites abundant with their habitat locations.

\section{A.1.1. Suborder: Acaridida} (Astigmata). Canestrini 1891:

The most common abundant families was Acaridida the commonest species was Dermatophagoides pteronyssinus (Trouessart). The Acaridida is a large assemblage of primarily terrestrial mites which with few exceptions are non predatory in habit. Many species are exclusively Saprophytic, fungivorous or graminivorous and several groups are exclusively parasitic. Most Acaridida are slow -moving, weakly or incompletely sclerotized mites which range in size from 200 to 1800 um Krantz and Walter (2009). In this study, as shown in Table (1), the collected astigmatid mite species which collected from different stored products materials were $\mathbf{3 4}$ different species in 19 genera and 7 families. The families and genera were (Acaridae), Caloglyphus rhizoglyphoids, C. stammeri, C. berlesei, Rhizoglyphoids robini, R. echinopus (Banks) Acarus siro, A. farrie, A. gracilis, A.immobilis. Aleuroglyphus ovatus, Lardoglyphus zacheri, Tyrophagus tropicus, T. Iongior, T. putrescentia, Tyrolichas casie and Thyreophagus entomophgus and 8 species belonging to family Glycyphagidae, Lepidoglyphus michaeli, L. destructor, Glycyphagus ornatus, G. bycaudatus, G. domesticus, Austrogly cyphagus, Blomia feeemani and Gohieria fusca. The mites of the family Pyroglyphidae in this study were Dermatophagoides D.pteronyssinus, farinae, Euroglyphus maynei, D.microceras, araneola (Grandjean) Pyroglyphus africanus and Gymnoglyphus carmlitus. On the other hand, there were 2 speceis belonging to family Carpoglyphidae; Carpoglyphus lactis and C. munroi and 2 speceis belonging to family Suidasidae; Suidasia nesbitti and Suidasia medanensis.

\section{A.1.2. Suborder: Actinedida (Prostigmata) :}

The Prostigmata is a suborder of mites belonging to the Trombidiformes, which contain the sucking members of the true mites (Acariformes). Some of the prostigmata parasitizing vertebrates are of medical relevance due to causing skin diseases in human, many of them live associated with stored products and food stuffs and others live in soil. In the current study, Table (1) showed the presence of 22 different prostigmatid mites associated with different stored products materials in 13 genera in 7 families: Cunaxsidae: Cunaxa capreolus (Berlese), Conaxa woners leyi (Baker and Haffmann), Neocunaxoi desandrei (Baker\&hoff.); Cheyletidae: Acaroesis sollers, Cheyletus badryi, Cheletogenes ornatus (C.\&F.) C. linsdalei (Baker), C. malaccensis, C. davisi, C. troussart (Oud.) C.bologhi, C. eruditus, C. vorax, Acaropsellina docta; Caligonellidae: Molothrognthus minutes; Bdellidae: Spinibdella corticic (Ewing), Cyta latirostris (Hermann); Tydeidae: Orthotydeas californicus (Banks), Lorryia ferula (Baker); Smarididae: Trichomaris jacoti (Southcott); Raphignathoidea: Raphignathus ehari (Zaher\&Gomaa), Raphignathus niloticus (Gomaa\& Hass) and family Stigmaeidae: Apostigmaeus aegypticus (Soliman\& Gomaa).

\section{A.1.3. Suborder: Gamasida (Mesostigmata):}

The present study, Table (1) indicated that there are $\mathbf{2 1}$ different mesostigmatid mites belonging to 11 genera and 6 families as follows: Family Ascidae: 
Wedad A. Atwa, et al.,

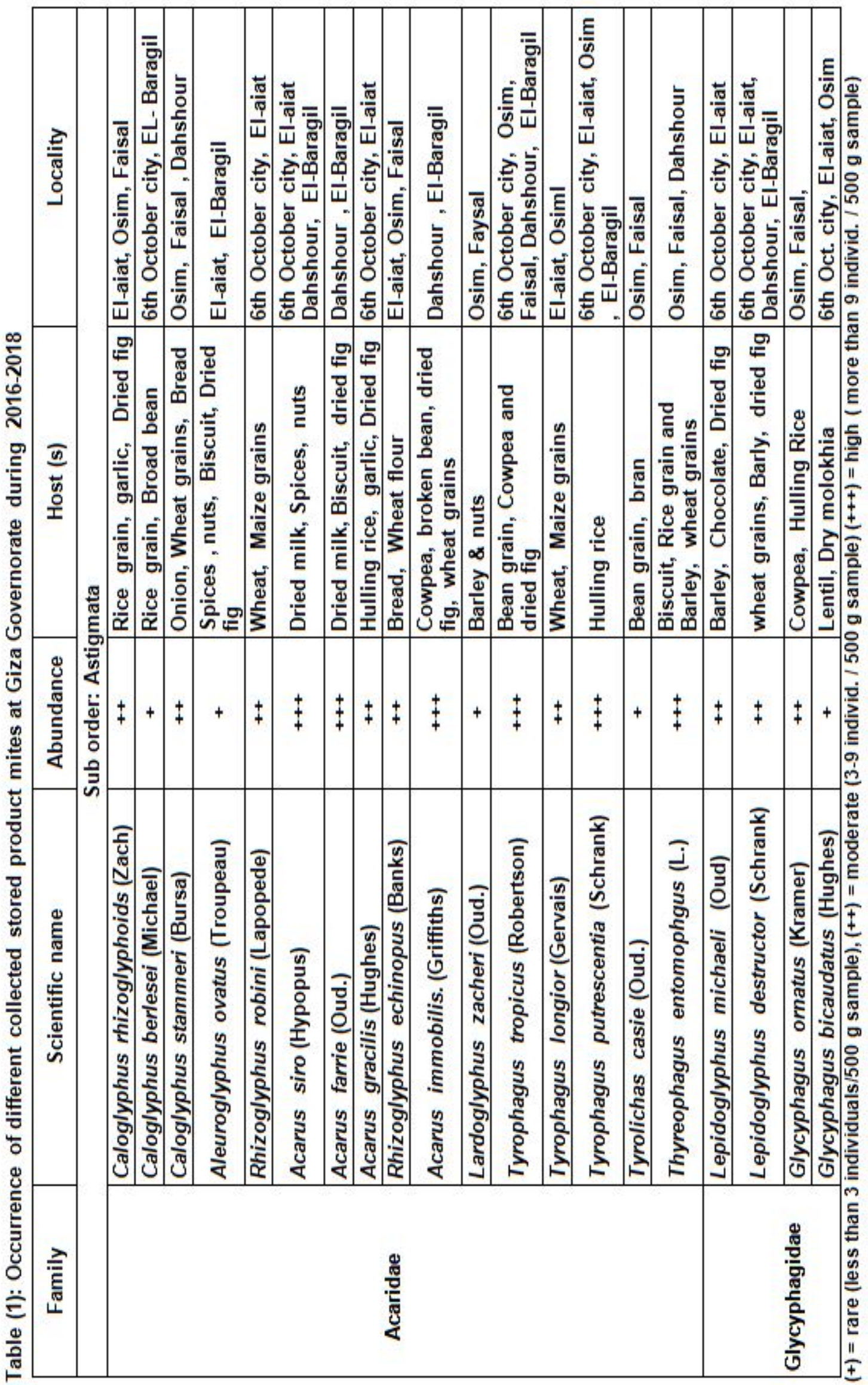




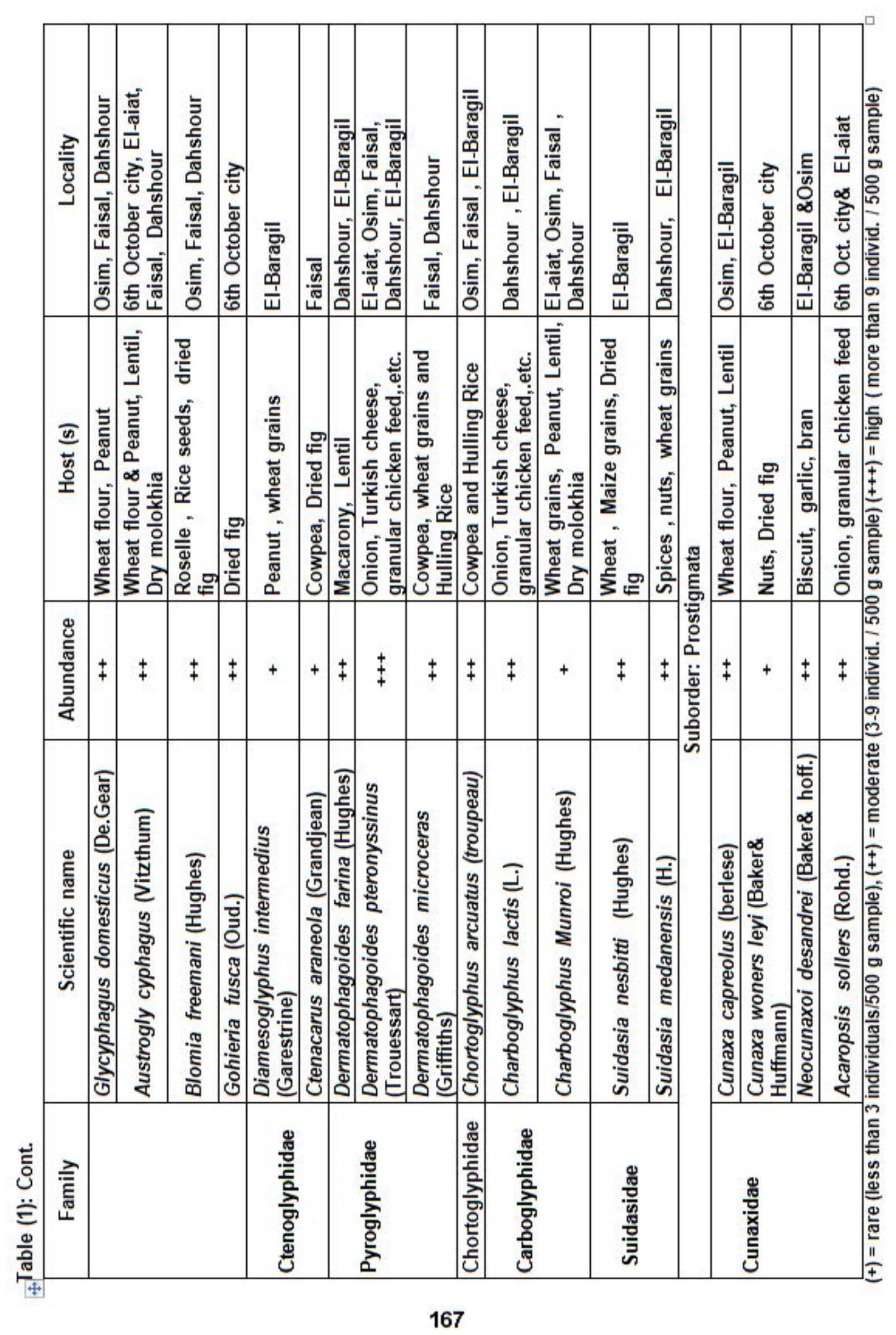


Wedad A. Atwa, et al.,

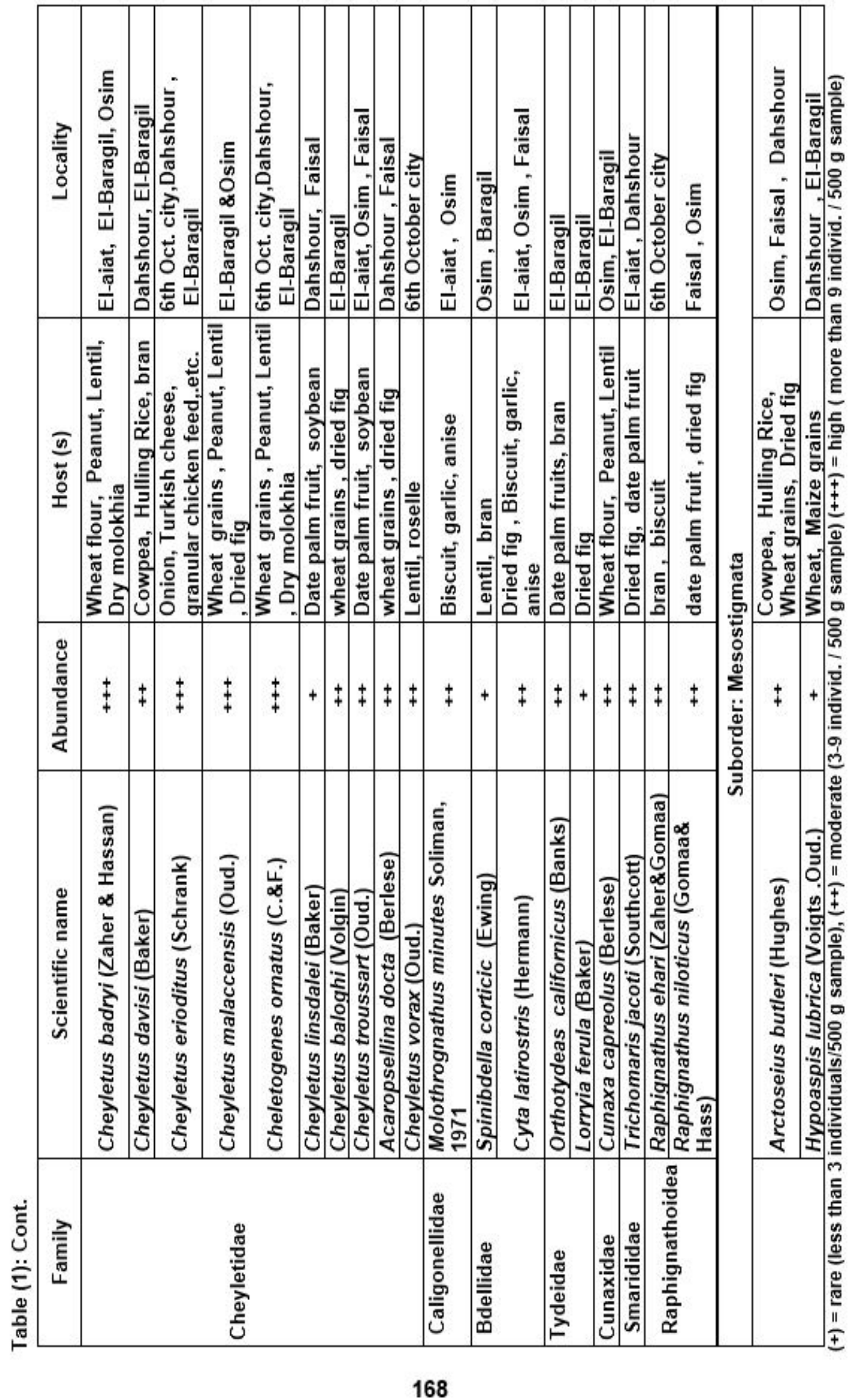




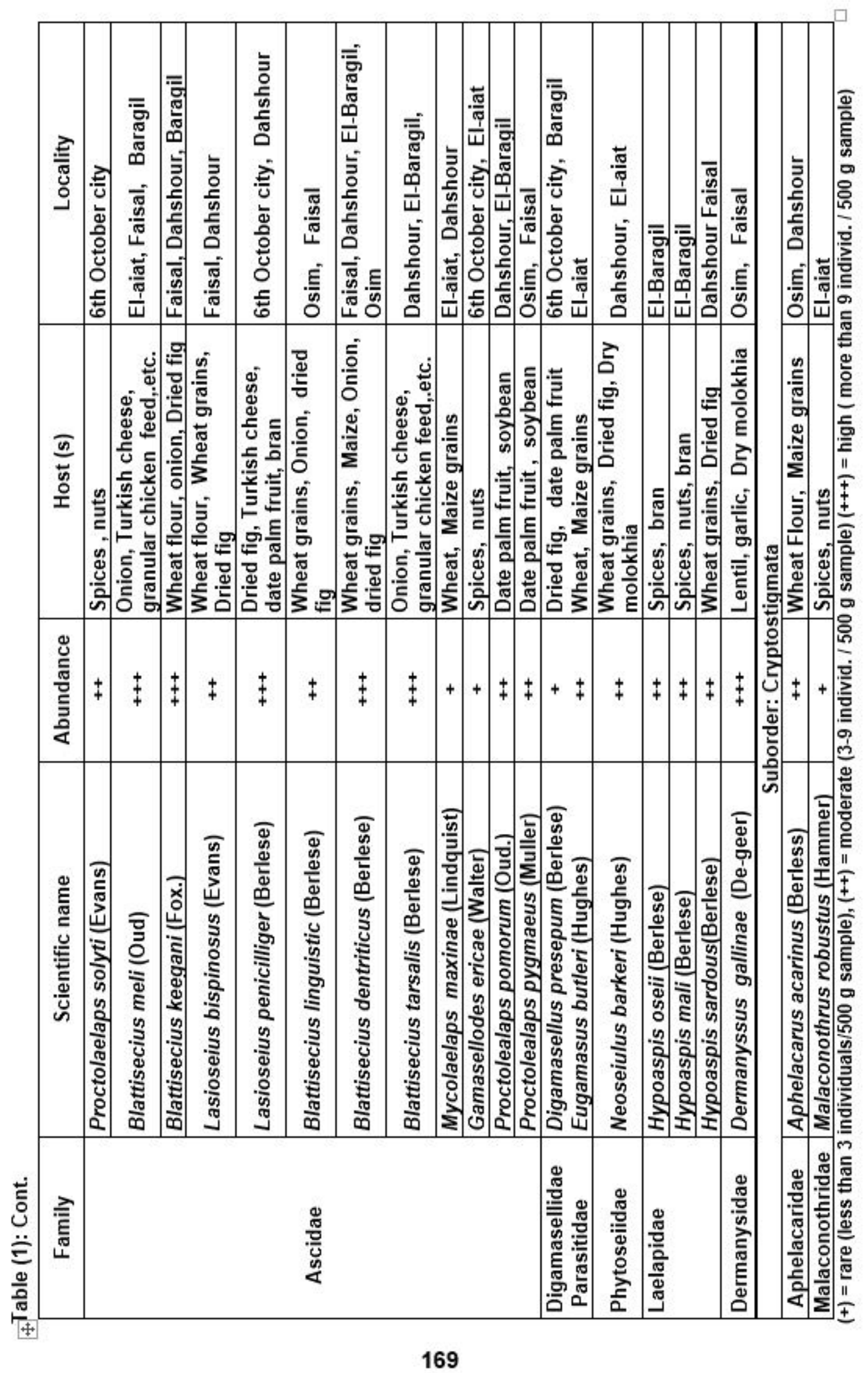


Wedad A. Atwa, et al.,

Arctoseius butleri (Hughes), Hypoapis lubrica (Noigts Oud.), Proctolaelaps solyti (Evans), Blattisecius meli (Oud.), Lasioseius bispinosus (Evans), Lasioseius penicilliger (Berlese), Blattisecius linguistic (Berlese), Blattisecius dentriticus (Berlese), Blattisecius tarsalis (Berlese), Mycolaelaps maxinae (Lind quist), Gamasellodes ericae (Walter) Proctolealaps pomorum (Oud.), Proctolealaps pygmaeus (Muller). Digamasellidae: Digamasellus presepum (Berlese), Parasitidae Eugamasus butleri (Hughes). Phytoseiidae: Neoseiulus Barkeri (Hughes) Laelapidae: Hypoaspis oseii (Berlese), Hypoaspis miles (Berlese), Hypoaspis sarrdoa (Berlese) and Dermanysidae: Dermanyssus gallinae (De-geer).

\section{A.1.4. Suborder Oribatida (Cryptostigmata):}

The oribatid mites in this study represented with 2 species in 2 genera and 2 families as follows: Aphelacaridae: Aphelacarus acarinus (Berlese) and Malaconothridae: Malaconothrus robustus (Hammer).

These results are confirmed with those obtained by El Nggar et al., (1992) who recorded 53 mites species associated with stored grains in Egypt, of those, ten species belonging in five families of astigmatid mites. The highest number of mite's species was found associated with squash seed and peas. Fawzy (1996) surveyed 50 of stored mites belonging to 42 genera and 17 families from different stored products, stored flour, rice, maize, animal milk, wheat bran, dried fruits, rice germ, Turkish cheese, cotton seeds, bean, akalona of wheat, and house dusts.

El-Sanady (1999) collected twenty-four species of astigmatid mites from different localities of Egypt associated with fifteen materials of stored products. She mentioned that the family Acaridae was found to be the most common family of the storage Acari, which represented by thirteen species. She added that the high population was found in wheat and wheat bran.

Mohamed (2003) recorded 105 different species of stored products belonging to 60 genera and 31 families under four suborders (Astigmata, Prostigmata, Mesostigmata, Pyroglyphidae, Chortoglyphidae, Glyciphagidae, Suidasidae, Acaridae, and Tyroglyphidae ).

Mostafa et al., (2006) recorded 93 species of mites belonging to 53 genera, 26 families and 4 sub orders association stored products at 16 Egyptian Governorates.

Yassin et al., (2009) noticed that the most abundant family collected was Pyroglyphidae representing $27.27 \%$ of the total number distributed between two different species of the Genus Dermatophagoides (D. pteronyssinus and $D$. farinae). This followed by families Cheyletidae and Dermanyssidae; each comprises $25.75 \%$ of the total with a single species for each; $C$. malaccensis and Dermanyssus sp. Respectively. Family Acaridae was represented by (21.21\% of the total) and came later in abundance.

Abou El- Enien (2011) The study proved the occurrence of 102 mite species belonging to 64 genera in 30 families and 4 suborders: Astigmata, Prostigmata, Mesostigmata and Cryptostigmata. The astigmatid mite species which collected from different stored products materials were 34 different species in 20 genera and 8 families the actinedid mites in this study included 43 different mite species in 26 genera belonging to 14 families. Also, there were $\mathbf{2 5}$ mites' species belonging to 
16 genera in 8 families belonging to the suborder Mesostigmata .

Abdel-Khalik (2013) surveyed the mites associated with different stored products at different areas at Menofia Governorate. Data proved the occurrence of 82 mite species belonging to 54 genera under 30 families belonging to 4 suborders.

A.2. Occurrence of mites in $\mathbf{5 0 0} \mathbf{~ g m}$ in $\mathbf{5 0}$ samples collected from El- Giza Governorates during the period of study from 2016 to 2018:

The graphically illustrated in Fig. (1) Showed the total number and percentage of the different collected Food products mites families. The study indicated that the Acaridae mites number was 158 different mite with ratio of 14.4 of the total collected families followed by the different families: Pyroglyphidae (11.2\%), Cheyletidae (11.2\%), Ascidae (11.1), Laelapidae (10.4) Glycyphagidae (7.9\%), Suidasidae (5.2 \%) Bdellidae (5.1), Cunaxsidae (4.2\%), Caligonellidae (1.4),
Raphignathoidea (3.1), Parasitidae (2.0), Carpoglyphidae (1.7), Ctenoglyphidae (1.5\%), Dermanyssidae (1.6), Tydeidae (1.6), Smarididae (0.7), Chortoglyphidae (1.1), Digamasellidae (1.1), Phytoseiidae (0.9), Aphelacaridae (0.6) and Malaconothridae (0.5).

\section{A.3. Population dynamics study:}

During the study season from (2016 to 2018), the wheat grains and Dried fig fruits had chosen to estimate the infestation of the different mites to these hosts at Dahshour region, Giza governorate, it was found that the commonest collected mites were belonging to suborder Acaridida, Actinedida and Gamasida.

\section{A.3.1. Wheat grains:}

In this study, the most common collected mites associated with Wheat grains were belonging to suborder: Acaridida, Actinedida and Gamasida as shown in Figures (2\&3).

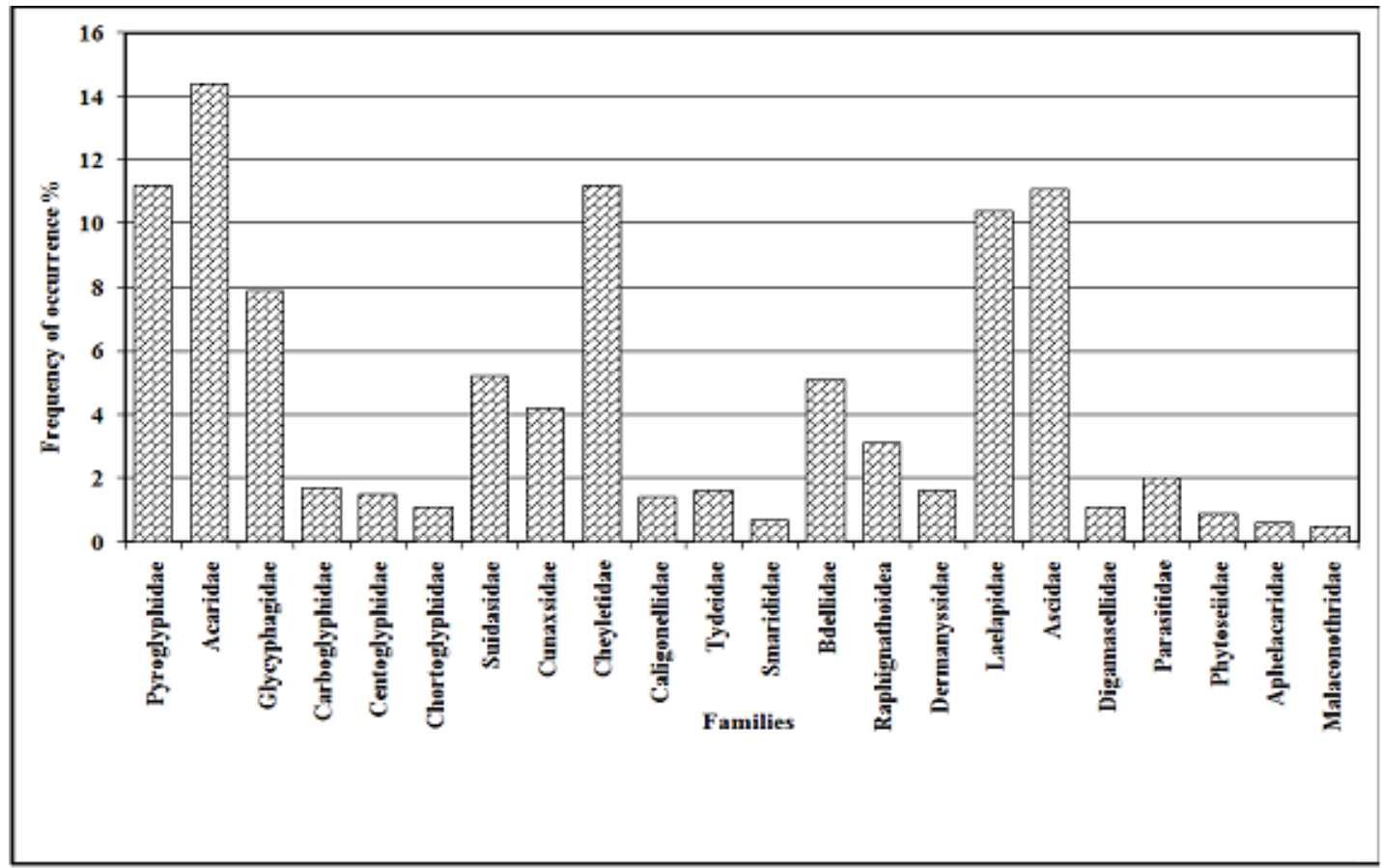

Fig. (1): Frequency of occurrence (F.O.\%) mite families collected from $500 \mathrm{gm}$ in 50 samples at El- Giza Governorate during the period of study from 2016 to 2018. 
Wedad A. Atwa, et al.,

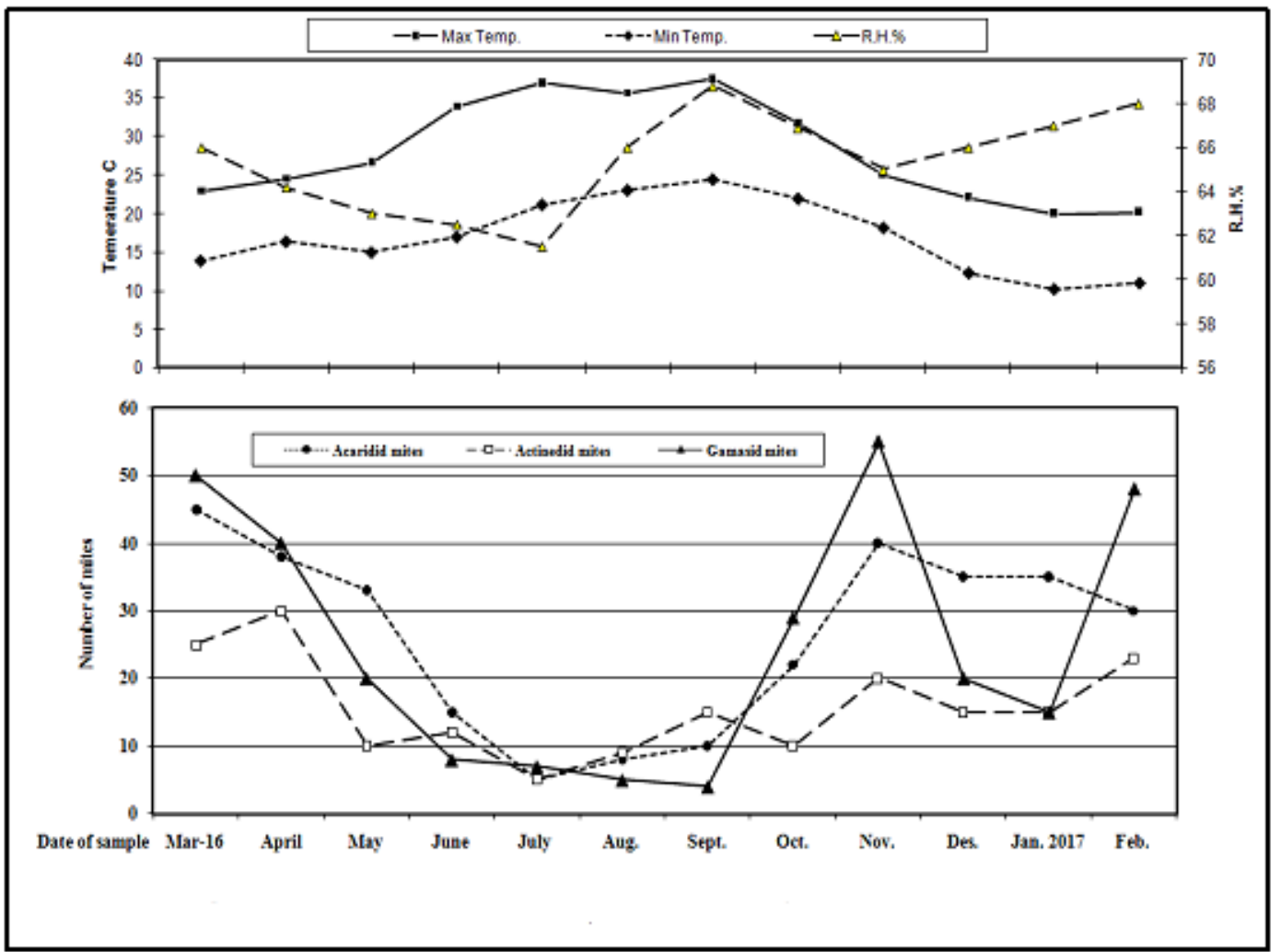

Fig. (2): Population dynamics of the collected mites associated with wheat grains during 2016/2017 at Dahshour region, Giza Governorate.

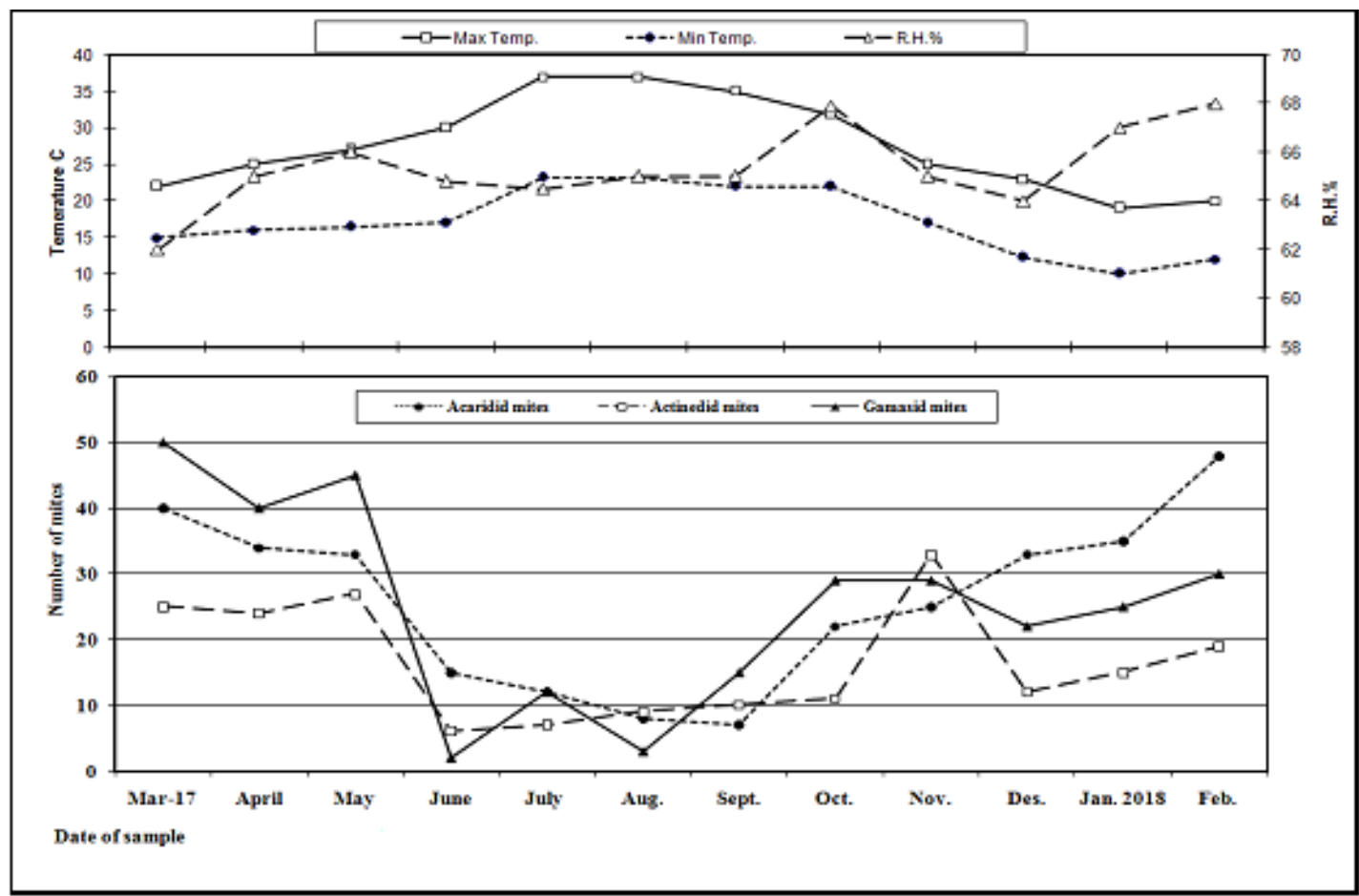

Fig. (3): Population dynamics of the collected mites associated with wheat grains during 2017/2018 at Dahshour region, Giza Governorate. 
During 2016/ 2017 season, the highest population of astimatid mites was 40 and 45 mite individuals during November and March, respectively. The lowest level is recorded during July and August (5 and 8 mite individuals), respectively. On the other hand, the actinedid mites (Prostigmata) showed the highest level of abundant during March and April (25 and 30 mite individuals), respectively and the lowest levels recorded during July and August (5 and 9 mite individual) however the gamasid showed the highest level of abundant during March and November (50 and 55 mite individuals) respectively and the lowest level was during August and September (5 and 4 mite individuals).

During 2017l 2018 season, the highest population of astimatid mites was 48 and 40 mite individuals during February and March, respectively. The lowest level is recorded during August and September (8 and 7 mite individuals), respectively. On the other hand, the actinedid mites (Prostigmata) showed the highest level of abundant during March and November (25 and 33 mite individuals), respectively and the lowest levels recorded during June and July (6 and 7 mite individual) However the gamasid showed the highest level of abundant during March and May (50 and 45 mite individuals) respectively and the lowest level was during August and June (3 and 2 mite individuals).

\section{A.3.2. Dried Fig fruits:}

The resulted data in Figure (4) clearly indicated that, during 2016-2017 seasons, the highest population of astimatid mites was 55 and 60 mite individuals during April and May, respectively. Whereas the lowest level is recorded during August and September (2 and 5 mite individuals), respectively. On the other hand, the actinedid mites (Prostigmata) showed the highest level of abundant during February and April (44 and 39 mite individuals), respectively and the lowest levels recorded during July and August (7 and 8 mite individual) However the gamasid showed the highest level of abundant during November and February (35 and 32 mite individuals) respectively and the lowest level was during August and June ( 3 and 8 mite individuals).

With respect to the data graphically in Figure (5), during 2017-2018 seasons, the highest population of astimatid mites was 50 and 65 mite individuals during March and May respectively. While the lowest level is recorded during July and August 2 and 2 mite individuals), respectively. On the other hand, the actinedid mites (Prostigmata) showed the highest level of abundant during March and April (35 and 32 mite individuals), respectively and the lowest levels recorded during June and August (8 and 5 mite individual) however the gamasid showed the highest level of abundant during March and April (35 and $\mathbf{4 0}$ mite individuals) respectively and the lowest level was during August and September ( 0 and 1 mite individuals).

Effect of certain biotic and a biotic factors on the abundance of acaridid, actinedid and gamasid mites inhabiting wheat grains and dry fig fruits:

The present study evaluate the relation between the biotic and a biotic factors and the population dynamics of the different mites inhabiting both wheat grains and fig fruits during 2016/2018 at Al-Giza Governorate. Correlation coefficient in Table (2\&3) gives the simple correlation value of different mites and (maximum and minimum temperature and relative humidity) together with their level of significant during the two tested season (2016/2017 and 2017/ 2018). The correlation values show the most of the tested factors expressed as significantly negative relation on the population of the collected acaridid, actiedid and gamasid mites except the effect of relative humidity which was negatively affected 
on wheat grain and dried fig. (Table $2 \& 3$ ). In addition, results showed that all tested factors separately or combined with each other were affected with non significantly relationship on the population dynamics of the collected acaridid, actinedid and gamasid mites in this region during the study periods.

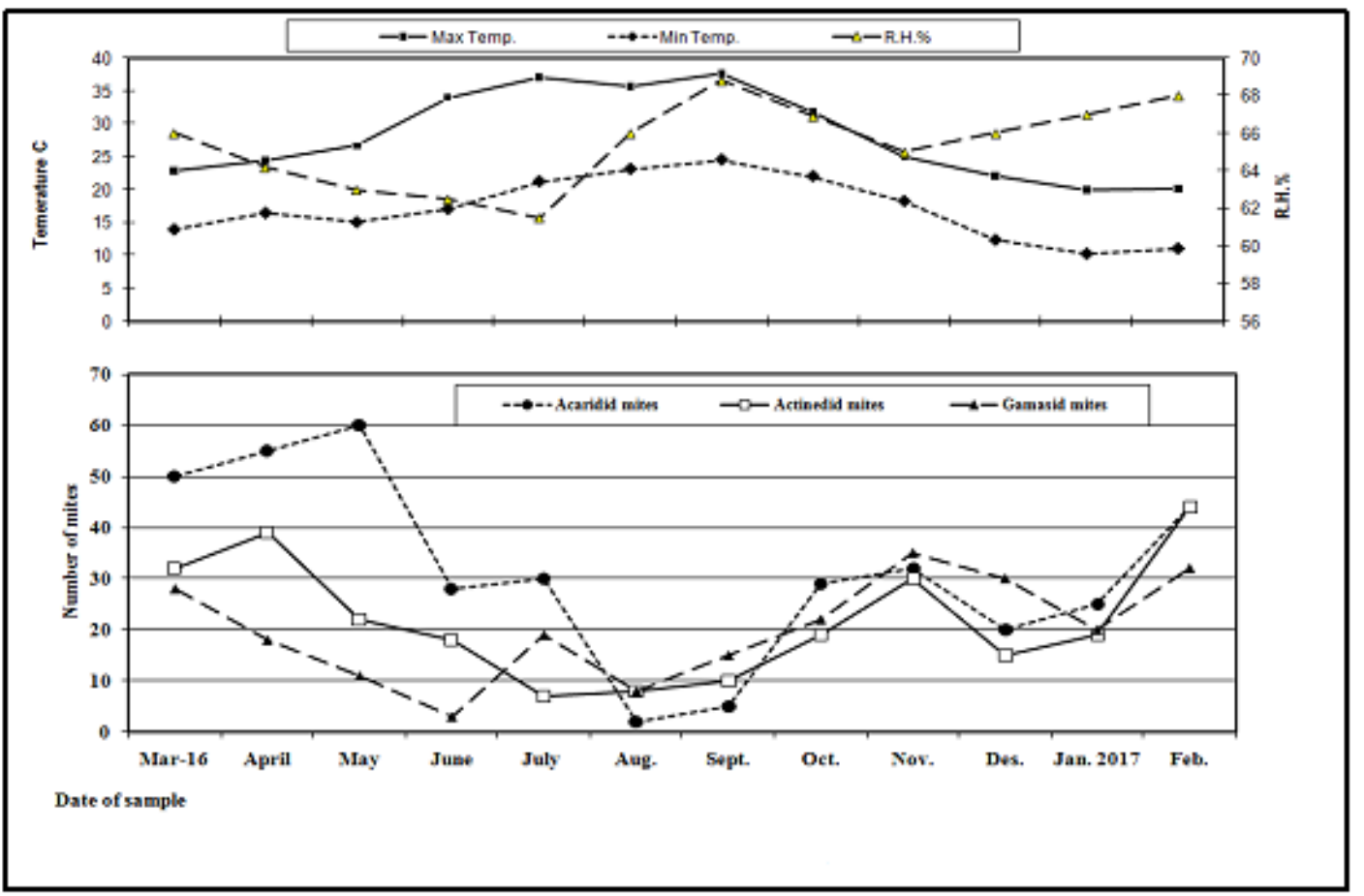

Fig. (4): Population dynamics of the collected mites associated with dried fig fruits during 2016/2017 at Dahshour region, Giza Governorate.

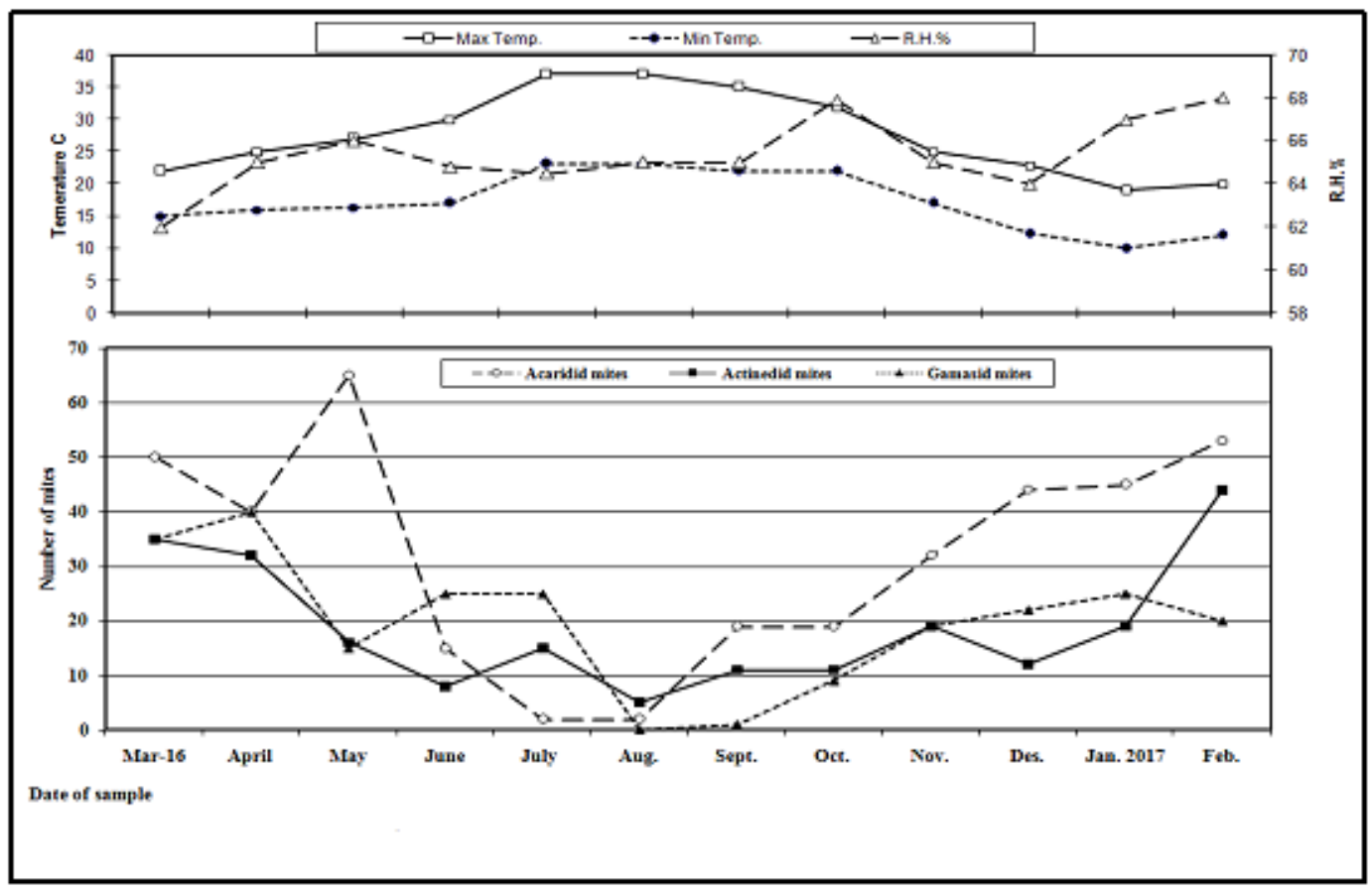

Fig. (5): Population dynamics of the collected mites associated with dried fig fruits during 2017/2018 at Dahshour region, Giza Governorate. 
Table (2). Correlation coefficient between abiotic factors and mites on wheat grain.

\begin{tabular}{|l|c|c|c|c|c|c|}
\hline \multirow{2}{*}{ Mites } & \multicolumn{3}{|c|}{ Season 2016/2017 } & \multicolumn{3}{c|}{ Season 2017/2018 } \\
\cline { 2 - 7 } & Max. Temp. & Min. Temp. & R.H. & Max. Temp. & Min. Temp. & R.H. \\
\hline Acaridid mites & $-0.89^{* * *}$ & $-0.72^{*}$ & 0.13 & $-0.91^{\star * *}$ & $-0.86^{\star *}$ & 0.16 \\
\hline Actinedid mites & $-0.64^{*}$ & -0.44 & 0.30 & -0.56 & -0.48 & -0.09 \\
\hline Gamasid mites & $-0.67^{*}$ & 0.42 & 0.17 & $-0.61^{*}$ & -0.50 & -0.05 \\
\hline Total mites & $-0.80^{* *}$ & -0.57 & 0.20 & $-0.78^{* *}$ & -0.68 & 0.01 \\
\hline
\end{tabular}

Table (3). Correlation coefficient between abiotic factors and mites on dried fig

\begin{tabular}{|l|c|c|c|c|c|c|}
\hline \multirow{2}{*}{ Mites } & \multicolumn{3}{|c|}{ Season 2016/2017 } & \multicolumn{3}{c|}{ Season 2017/2018 } \\
\cline { 2 - 7 } & Max. Temp. & Min. Temp. & R.H. & Max. Temp. & Min. Temp. & R.H. \\
\hline Acaridid mites & -0.53 & -0.52 & -0.37 & $-0.84^{* *}$ & $-0.81^{* *}$ & 0.09 \\
\hline Actinedid mites & $-0.71^{*}$ & -0.57 & 0.15 & $-0.67^{*}$ & $-0.62^{*}$ & 0.05 \\
\hline Gamasid mites & -0.63 & -0.40 & 0.37 & -0.58 & -0.55 & -0.33 \\
\hline Total mites & $-0.74^{*}$ & $-0.61^{*}$ & -0.03 & $-0.86^{* *}$ & $-0.83^{* *}$ & -0.04 \\
\hline
\end{tabular}

\section{REFERENCES}

Abdel-Khalik, A.R. (2013). Studies on the effect of certain mites on some food products. M.Sc. Thesis, Fac. Sci., Menoufia Univ., 104 pp.

Abou El- Enien, N.F. (2011). Ecological and biological studies on some mites associated with some cereal and stored products at Dakahlia Governorate. M.Sc.Thesis, Fac. Sci., (Girls), Al-Azhar Univ., 102 pp.

Duek, L., Kaufman, G. Palevsky and I. Bericevsky (2001). Mites in fungal cultures. Mycoses, 44 (9-10): 390-394.

El- Naggar, M.E., M.A. Rakha and H.A. Taha (1992). Mites of stored grains in Egypt .Egypt. J. Biol. Pest Control, 2(2): 109- 122.

El-Sanady, M.A. (1999). Biological studies on mites associated with stored products. M. Sc. Thesis, Fac. Sci., Cairo Univ., 108pp.

El-Sanady, M. A. (2005). Studies on some stored product mites and their predators. Ph.D. Thesis, 193pp. Fac. Sc. (girls) Al-Azhar Univ. Egypt

El-Sayed, M.E. (2017). Mites inhabiting stored products and its role in the biological control program in Egypt. M.Sc. Thesis, Fac. Sci., Zagazig Univ.,128 pp.

Fawzy, M.M. (1996). Biological studies on house dust mites. Ph.D. Thesis Fac. of Agric. Cairo Univ., 227 pp.

Griffiths, D.A. (1960). Some field habitats of mites of stored food products. Ann. Appl. Biol., 48(1): 134-144.

Harein, P. and R. Meronuck (1995). Stored grain losses due to insects and molds and the importance of proper grain management, In V. Krischik, G. Cuperus \& D. Galliart, pp 29-31. E912.CES. Div. Agric. Sci. Nat. Res. OSU. USDA. FGIS. ES. APHIS,242pp.

Hughes, A.M. (1976). The mites of stored food and houses. Tech. Bull., Min. Agric. And Fisheries in London, 63: 105-110.

Hubert, J.V. Stejskal, A. Kubatova, M. Vanoza and Z. Munzbergova (2003). Mites as selective fungal carries in stored grains habitate. Exp. Appl. Acarol., 29:69-87.

Johnston, D.E. (1975): Acarologists of the wodled. $10^{\text {th }}$ ed., Internat. Conger. 
Wedad A. Atwa, et al.,

Acarol., and Acarol. Lab., Ohio State Univ.

Karg, W. (1971). Die freilebenden Gamasina (Gamasidae), Raubmilben. Die Tierwelt Deutchlands, 59: 475 pp.

Krantz, G.W.and D.E. Walter (2009). A Manual of Acarology. Texas Tech Univ.Press, 807pp.

Lindquest, E.E. and G.O. Evans (1965). Taxonomic concepts in the Ascidae, with a modified setal nomenclature for the idiosoma of the Gamasina (Acarina: Mesostigmata). Mem. Ent. Soc. Can., 47: 1-64.

Mohamed, A.A. (2003). Studies on some mites associated with cereals and stored products in Egypt. M.Sc. Thesis, Fac. Sci., (Girls), Al-Azhar Univ., 103 pp.

Mostafa, A.M., E.M. Fatma, E.M.A. Yassin and A.A. Mohamed (2006). Occurrence of mite species associated with stored products in Egypt. Egypt. J. Appl. Sci., 21(12a): 227- 236.

Olsson, S. and V.H. Hamsten (2000). Allergens from house dust and storage mites: similarities and differences, with emphasis on the storage mite Lepidoglyphus destructor. Clin. Exp. Allergy, 30:912919.
SAS Institute (2010). SAS Statistics and Graphics Guide, Release 9.1. SAS Institute, Cary, North. Carolina 27513, USA.

Solomon, M.E. (1946). Tyroglyphid mites in stored products. Ecological studies. Ann. Appl. Biol. 33:82-97.

Summer, F. A. and D.W. Price (1970). Review of the mite family Cheyletidae Univ. California Pupl. Ent. 61:153 PP.

Yassin, M. K; Z.E. Ashmawy and A.A. Hasanin (2009): Study the quality of school environment as new habitat for allergenc mites in Cairo, Egypt. Egypt. Acad. J. Biolog. Sci., 1 (1): 103- 116.

Zaher, M.A. (1984). Survey and ecological studies on phytophagous, predaceous and soil mites in Egypt. 1Phytophagous mites in Egypt (Nile valley and Delta). PL-480 Program. USA Project No. EG-ARS-30. Grant No. FG-EG-193, 228pp.

Zaher, M.A. (1986). Survey and ecological studies on phytophagous, predaceous and soil mites in Egypt. PL- 480 Program. USA Project No. EGARS-30. Grant No. FG-EG-139, 567pp.

Zdarkova, E., P.H. Verner, and J. Novosad (1983). Dispersion and distribution of mites and beetles in stored grain. $J$. Stored Prod. Res., 19:73-80. 
دراسات بئيه علي الأكاروسات المفترسة والمتطفلة المرتبطة ببعض المنتجات المخزونة

وداد احمد عطوة(')، محمود السيد النجار (ץ) ، عابدين محمود خليل(؟)، منال السيد الثاعر(') ،

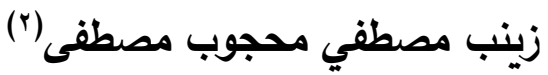

(1) (1) قسم علم الحيوان - كلية العلوم - جامعة الأزهر

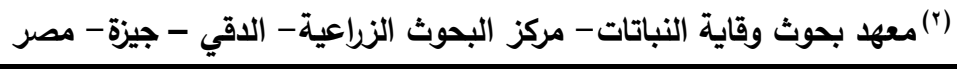

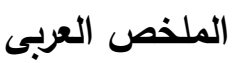

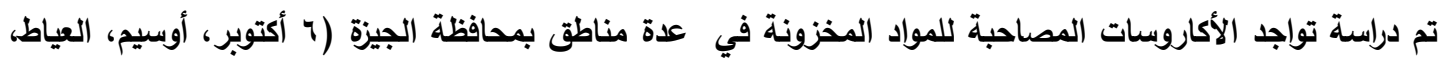

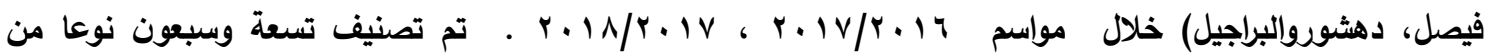

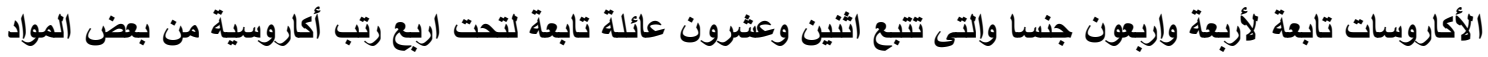

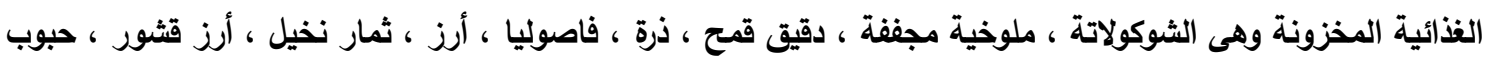

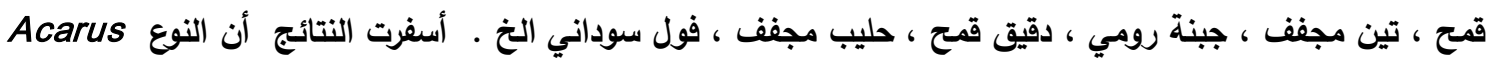
Blomia freemani Dermatophagoides pteronyssinus farrie العينات المدروسة. بينما كانت أكثر المقترسات شيوعا هى Blattisecius keegani، Cheletogenes ornatus، Hypoaspis oseii

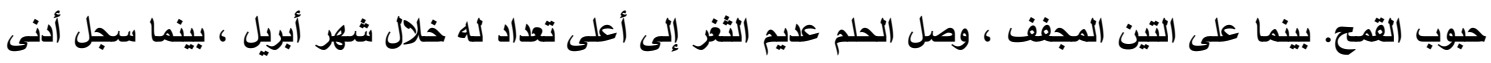
مستوى له خلال شهر أغسطس ، خلال موسمى الدراسة.

$$
\begin{aligned}
& \text { أسماء السبادة المحكميني } \\
& \text { أ.د/ محمد الأمين سويــــ كلية الزراعة - جامعة المنوفية }
\end{aligned}
$$


Wedad A. Atwa, et al., 